lococcal nuclease to follow conformational changes on denaturation and the effects of binding small molecules to the protein. Unfortunately, their paper consists simply of a summary of their results, and unless the reader is already familiar with their elegant deuteration technique the impact of this important paper will be lost. Raftery and Parsons show how one can study inhibitor and substrate associations with lysozyme by measuring the chemical shift changes which occur when the small molecules bind to the protein.

A novel method for obtaining conformational information for fibrous proteins is described by Chapman and co-workers. By replacing the exchangeable protons with deuterium in molecules such as collagen and observing the doublet splittings in the deuterium spectrum when the fibre axis is coincident with the applied magnetic field they were able to interpret the splittings in terms of the conformation of the backbone.

Because much of the work described at this meeting has also been presented in more detail in the scientific literature one might question the value of such a text. But because of the lack of any textbooks which cover adequately the applications of magnetic resonance in biology the existence of a volume of collected papers is not without value.

There is no reported discussion of the papers, and the book therefore fails to communicate any of the exchanges of ideas which surely take place at such a meeting and which would greatly have enhanced its usefulness. J. FEENEY

\section{Carnot Père}

Lazare Carnot, Savant. By Charles Coulston Gillispie. (A Monograph treating Carnot's Scientific Work, with facsimile reproduction of his writings on mechanics and on the calculus, and an essay concerning the latter by A. P. Youschkevitch.) Pp. xi+359. (Princeton University: Princeton, New Jersey; Oxford University: London, October 1971.) $£ 8.25$.

LAZARE CARnot is known to the general public as the "Organizer of Victory" of the French Revolutionary armies, and to physicists as the father of his elder son Sadi. He was, however, also a savant in his own right, and in this monograph Professor Gillispie gives us an account of his work in mechanics and, to a lesser degree, in geometry and the infinitesimal calculus.

His mechanics were soon overtaken by those of the mathematical giants of the late eighteenth and early nineteenth centuries, many of whom were his own countrymen--Lagrange, Laplace, Pois- son, Coriolis and Navier. What is still of great interest in his work is the extent to which it influenced Sadi's pamphlet of 1824, Réflexions sur la Puissance Motrice du Feu, et sur les Machines Propres a Développer cette Puissance. This work was once thought to have been almost an isolated phenomenon in the history of thermodynamics, without parentage and, for many years after its publication, without issue also. It is now becoming clear that its apparent isolation is a myth. Thus it has been accepted for some years that Sadi's ideas on the flow of heat (how the old "caloric" language still pervades our thought!) from a higher to a lower temperature were influenced by his father's on the flow of water in the operation of hydraulic machinery. More recently Fox has emphasized what Sadi owed to Watt and the practical engineers. Now Gillispie argues persuasively that an even stronger influence on Sadi's thought was his father's concept of "geometrical motions". These are essentially what we should now call virtual displacements, but embody also the important idea of reversibility. To get the best performance out of machinery we must avoid all shocks or percussions between surfaces moving at different speeds, just as we must avoid all transfer of heat across non-zero intervals of temperature if we are to get the best out of a heat engine.

The book includes facsimiles of three of Carnot's manuscripts, discovered by the author in the course of his research; two early memoirs on the theory of machines, and the earliest version of his work on the calculus. The last is introduced by an essay by Professor Youschkevitch of Moscow. The manuscripts are clearly all fair copies and so throw no light on the way Carnot's thoughts were running. Since even the most elegant French handwriting of the eighteenth century is tiring to read when printed in black on a grey background, it is hard to understand why these memoirs were not set in letterpress. However, there is so much to be grateful for in this handsome volume that perhaps we should not cavil at three fashionable facsimiles.

\section{J. S. RowLINSON}

\section{Fat Cells}

The Human Adipose Cell: a Model for Errors in Metabolic Regulation. By David J. Galton. Pp. viii +220 . (Butterworth: London, October 1971.) $£ 4$.

THIS slim volume on the human adipose cell is aimed primarily at physicians and postgraduate medical students whose knowledge of adipose tissue metabolism may be non-existent or in need of a brush up. The author has explained in the preface that this is a book which covers the field extensively and superficially rather than in depth and is therefore unlikely to be suitable for research workers. The field of adipose cell physiology and biochemistry has developed explosively following the pioneering studies of Wertheimer. It is important in relation to nutrition, diabetes, obesity and atherosclerosis, and the adipose cell has illuminated studies of fat and carbohydrate metabolism, metabolic regulation and hormone action. There are at least three recent books with papers by distinguished workers in the field which review various growing points in the subject. Adipose tissue is not usually well covered in physiology or biochemistry texts and since much of the knowledge of this important tissue is very recent there may well be many with little knowledge of it. There is thus a need for an elementary text both to convey knowledge about this cell and to put across the dogma and jargon of eukaryote metabolic regulation to excite the growth of clinical investigation. This book could succeed but it has three shortcomings. In many instances I felt that the reader would be left in the air with no guidance as to where to go for more detailed knowledge of a particular topic that might be of interest. The book contains a number of irritating errors, some of which are unfortunate and will not be obvious to those whom it is designed to instruct. The bibliography is given in relation to numbers in the text and is not arranged in alphabetical order of authors. This is a pity because the book contains references to much scattered work on human adipose cells which has been poorly reviewed elsewhere. Any other presentation of the bibliography could have made the book a useful work of reference on human fat cells.

The book can be recommended as a modest account of metabolic regulation in animals as exemplified by the fat cell and as a source of reference for work on human adipose tissue metabolism in which field the author is known as an original contributor.

P. J. RANDLE

\section{Trematodes in Molluscs}

Flukes and Snails. By C. A. Wright. (No. 4.) Pp. $168+16$ plates. (George Allen and Unwin: London, November 1971. ) $£ 3.25$ cloth; $£ 1.75$ paper.

THE book concentrates on the larval stages of the digenetic trematodes and their relationships with their molluscan 